\title{
Planning and management in the Missional agenda of the 21st Century Church: A study of Lighthouse Chapel International
}

\begin{tabular}{|c|c|}
\hline \multicolumn{2}{|c|}{$\begin{array}{l}\text { Authors: } \\
\text { Peter White }{ }^{1} \\
\text { Benjamin O. Acheampong }{ }^{2}\end{array}$} \\
\hline \multicolumn{2}{|c|}{$\begin{array}{l}\text { Affiliations: } \\
{ }^{1} \text { Department of Science of } \\
\text { Religion and Missiology, } \\
\text { University of Pretoria, } \\
\text { South Africa }\end{array}$} \\
\hline \multicolumn{2}{|c|}{$\begin{array}{l}{ }^{2} \text { Department of Theology, } \\
\text { Christian Service University } \\
\text { College, Ghana }\end{array}$} \\
\hline \multicolumn{2}{|c|}{$\begin{array}{l}\text { Corresponding author: } \\
\text { Peter White, } \\
\text { pastor_white@hotmail.com }\end{array}$} \\
\hline \multicolumn{2}{|c|}{$\begin{array}{l}\text { Dates: } \\
\text { Received: } 19 \text { Sept. } 2016 \\
\text { Accepted: } 16 \text { May } 2017 \\
\text { Published: } 30 \text { June } 2017\end{array}$} \\
\hline \multicolumn{2}{|c|}{$\begin{array}{l}\text { How to cite this article: } \\
\text { White, P. \& Acheampong, } \\
\text { B.O., 2017, 'Planning and } \\
\text { management in the Missional } \\
\text { agenda of the } 21 \text { st Century } \\
\text { Church: A study of Lighthouse } \\
\text { Chapel International', Verbum } \\
\text { et Ecclesia 38(1), a1699. } \\
\text { https://doi.org/10.4102/ } \\
\text { ve.v38i1.1699 }\end{array}$} \\
\hline \multicolumn{2}{|c|}{$\begin{array}{l}\text { Copyright: } \\
\text { (C) 2017. The Authors. } \\
\text { Licensee: AOSIS. This work } \\
\text { is licensed under the } \\
\text { Creative Commons } \\
\text { Attribution License. }\end{array}$} \\
\hline \multicolumn{2}{|c|}{ Read online: } \\
\hline 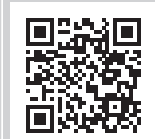 & $\begin{array}{l}\text { Scan this QR } \\
\text { code with your } \\
\text { smart phone or } \\
\text { mobile device } \\
\text { to read online. }\end{array}$ \\
\hline
\end{tabular}

Planning and management is an important aspect of every successful organisation. In a similar way as the church participates in the missio Dei, it is essential that we consider planning and management as part of the missional tools for the management of the various resources God has given the church. Doing this, church leadership must join in with the Father (God) and the Holy Spirit to know what he wants to accomplish in their context as they plan and manage God's resources for missional purposes. In the light of this understanding, the article discusses the role of 'planning and management in the missional agenda of the 21st century church' by using one of the fastest growing Neo-Pentecostal churches in Ghana, the Lighthouse Chapel International, as a case study. The central argument in this paper is that although leadership has a major role to play in missional planning, it is however a holistic and all-inclusive agenda. Missional planning includes the involvement of the Holy Spirit, congregational leadership, the entire congregation and the various resources the church is being endowed with by God.

Intradisciplinary and/or interdisciplinary implications: The study is an interdisciplinary study between Missiology, Planning, and Management. The result from the study will enhance the Ecclesiastical Community to appreciate the importance of management and planning as they participate in the missio Dei.

\section{Introduction}

A few years ago it could be said that the church did not pay much attention to the role of effective planning and management as part of its core mandate of building the body of Christ. In situations where planning was done, ensuring the effective implementation and management of plans was always a challenge. Continuing this attitude into the 21st century might have several negative effects on the church. In view of this, it is required of the church that although the gospel itself will not change, the approach, techniques and strategies of planning, administering and managing the church of the living God ought to change to meet the demands of our time. In this view, the article discusses the role of planning and managing the church in the fulfilment of the missio Dei with special focus on Lighthouse Chapel International (LCI).

Lighthouse Chapel International was founded in 1988 by Dag Heward-Mills ${ }^{1}$ and headquartered in Accra, Ghana. LCI has more than 1800 branches in 79 countries worldwide (Africa, Europe, Asia, the Caribbean, Australia, the Middle East and the Americas). Stewart and Nadia remarked that LCI is one of the largest of the Pentecostal churches that have appeared since the late 1970s in cities in Africa (Stewart \& Nadia 2009:170). It is one of the largest of the charismatic churches in Ghana, which have steadily drawn membership away from traditional churches (Aboderin 2011:71). The word international in the church's name reflects the common emphasis on success in charismatic Christian churches in Ghana, as does the term 'the Megachurch' that it commonly uses to describe itself (Sanneh \& Carpenter 2005:85). LCI is a member of the National Association of Charismatic and Christian Churches and the Pentecostal World Fellowship (Quampah 2014:144).

Lighthouse Chapel International is used for this study because of their consistent passion for mission. They are one of the few Neo-Pentecostal churches in Ghana that have successfully

1.Bishop Dag Heward-Mills is the founder and presiding bishop of Lighthouse Chapel International. He has served on the Church Growth International Board since 1996 and is the founder of the National Association for Charismatic and Christian Churches in Ghana. He was recently elected as an executive councilman of the Pentecostal World Fellowship. Before moving into full-time ministry in 1990, he was a medical doctor. 
applied planning and management in their mission agenda. LCI has also made good use of technological advancement in their discipleship programme, leadership development and management, stewardship and mission. Their tent missionary approach for church planting has also been well managed.

It should be noted at this point that the purpose of this paper is not to project planning and management of the church as a major missional tool for the church, but however, one of the missional tools to be considered in the management of the various resources (spiritual, material, physical and financial) the church has been blessed with.

The concern for writing this article is that many of the nonmainline churches in West Africa and more especially in Ghana are not really doing well in this aspect (management and planning) of the missional life of their churches. We are hopeful that this article would ignite church leaders not to only look at the spiritual aspect of the church but also the various resources they are endowed with.

\section{The nature of the 21st century church and mission}

Though the concept of what it means to be a 'church' has remained unchanged, the 21st century church has found itself in a complex context of technological advancement, secularised and modernised society and issues of Human Rights. The world has now become a global village and what happens in one context affects the other in various ways. Kemper (2016) described missionary service in the 21st century as following the New Testament's mission mandate to move outwards from Judea into all parts of the world. In the 19th century, parts of Africa, Asia and Latin America were considered to be suitable areas for mission. However, he held that mission theology and practice today and in the future are being shaped primarily by a global, ecumenical impulse that respects cultural diversity, promotes mission partnerships and understands that mission and missionaries must come from everywhere and be sent everywhere. In the book, Missions now: This generation, Greenway and Kyle (1990) examined the trend in missions and forecasted that the youth will spearhead missionary activities in the 21st century. Greenway and Kyle argue that unlike in the centuries past, the coming youth are generally idealistic, optimistic, committed and flexible, which are characteristics required of a Christian who enters into a cross-cultural ministry (1990:17).

The mass media also presents a golden opportunity for the 21st century church as another means of participating in the missio Dei. Furthermore, social media has also introduced a new reality in which each individual can create a threshold that works for him or her and move it as and when required. It gives one the opportunity to connect or communicate with hundreds of thousands of people (Nadella 2013:2). On the other hand, the 21st century church is also faced with issues of terrorism and a prosperity gospel.

\section{The concept of management and planning}

Rush defines management as a process of meeting the needs of people as they work at accomplishing their jobs (Rush 2003:3). It involves working constructively with resources to accomplish organisational goals. According to Means (2008:350), management relates more closely to the stewardship of human and capital resources. Management therefore requires effective and efficient coordination of all resources through the process of planning, organising, directing and controlling in order to attain a stated objective.

From a missiological perspective, the Harvestime International Institute defines management as a process of accomplishing God's purposes and plans through the proper use of human, material and spiritual resources. According to them, management is another word for stewardship (Harvestime International Institute 2001:6). The concept of management has four major functions: planning, organising, leading and controlling (Dayton \& Fraser 1990:19).

Although the concepts of planning and management are not the same, they move together. The role of managers is to plan and implement those plans. Planning is viewed by many scholars and treated in many theories as one of the functions of management. Planning is viewed as the primary management function because it establishes the basics for all the other functions that managers perform (Robbins \& Coulter 2002:177). Planning is a critical component of organisational success of which the church is not an exception. Planning is the systematic process of establishing a need and then working out the best way to meet the need, within a strategic framework that enables you to identify priorities and determines your operational principles (Shapiro 2003:4).

Robbins and Coulter defined planning as defining the organisation's goals, establishing an overall strategy for achieving those goals and developing a comprehensive set of plans to integrate and coordinate organisational work (Robbins \& Coulter 2002:176). Rush defined planning as consisting of identifying the overall purpose of a project, the activities to be performed, their sequence and the resources required to accomplish them (Rush 2003:17). A plan can therefore be defined as a scheme that specifies the future resources and action that an organisation needs in order to achieve its goal in an efficient and orderly way.

From the above definitions, it can be said that it involves anticipating future requirements and challenges. It also involves sequencing future resources and actions to minimise the delay and waste, which could arise if events were allowed to take their natural place and chronological order. Even though planning cannot eliminate change, managers plan in order to anticipate changes and develop the most effective response to them. 
In summary, the following are some of the benefits of planning:

- It helps us to focus our attention and efforts on the attainment of desired goals.

- It also leads to the proper and rational allocation of limited resources to the attainment of defined targets.

- Planning helps us to be proactive in life and not to be reactive.

- It minimises waste of time and other resources and promotes proper coordination of activities.

- It minimises delays and conflicts in decision-making as well as crisis management.

Having discussed the importance of planning and management as one of the missional tools of the church, it is however essential that the church subject her missional planning and management to the leading and direction of God by joining with the Holy Spirit to know what God wants us to do in our context.

This approach in other words is called missional discernment. According to Balia and Kim (2010:4), discernment is the first step in mission. In fact, there is no way the church can succeed in mission without engaging in missional discernment to know God's will for any mission venture they intend to embark upon (Ma \& Ross 2010:223, 241). The World Council of Churches $(2013: 52,56-57)$ submits that churches are called to discern the work of the life-giving Spirit sent into the world and to join with the Holy Spirit in bringing about God's reign.

Discernment is one way we connect with God. It is a part of spirituality that opens us to God's movement in our lives. It flows out of a larger commitment to yield our attention, agenda and action towards God. Discernment is an ongoing attitude and practice of Christian spirituality that matters to mission spirituality (White 2016:253-254). The local congregation in this regard is the basic unit of Christian witness and the environment in which discernment takes place (Hendriks 2004:31). Unlike in the secular idea of planning and management, missional planning and management begin with the missional leadership and the entire congregation's commitment to the leading of the Holy Spirit in their participation in the missio Dei.

\section{Spirituality of planning and management}

Spirituality is the core of the Christian experience and encounter with God in real life and action. It gives the deepest meaning to our lives and motivates our actions (Shorter 1978:4). When it comes to planning, no one is comparable to God, no matter how high a position they may hold in a country or in an organisation. Wagner (1987) concisely touched on the spirituality of planning strategies in his book 'Strategies for church growth'. He addressed the popular misconception that planning leaves no room for the sovereignty of God and the spontaneity of the Spirit's work and also rules out dependency upon the work of the Holy Spirit. He laid in brief the biblical and theological foundation for strategic planning. He held that it is essential that we, as citizens and subjects, know what the king is, what his purposes are for the world in which we live and what our roles are in contributing towards these purposes (Wagner 1987:12). Despite God's sovereignty and omnipotence, he chooses to use humans to fulfil his divine purpose.

Proverbs $16: 1,3^{2}$ teaches us that we are not sufficient of ourselves to think, or speak, anything of ourselves that is wise and good, but all our sufficiency is of God. In this regard, because the church is participating in the missio Dei, it is important that we join in with the Father (God) to work according to his missional plan for our society, community and church. Mission starts from God. Therefore, no matter how good a plan a church may have in its participation of the missio Dei, it is required that the plan(s) of each congregation ends with the final decision and the leading of God.

This echoes the view that the role of missional leadership is not in the first place in strategic planning or management, but in cultivating within the missional community the capacities needed for spiritual discernment and formation (Kim 2009:1, 40-66; Van Gelder 2007:107). According to the World Council of Churches (2013:56), pneumatological approach to mission exceeds and subverts our theological and ecclesiological boundaries and moves us into a new posture and practice of mission. In this regard, leaders stimulate the missional imagination of their congregation.

Sweets (2009:178) asserts that the church does not pass through time and context in hermeneutically sealed containers but rather like yeast that takes new form and changes every culture. Therefore, this calls for an incarnational mission spirituality and discernment to know the context for missional planning and participation (Roxburgh 2011:55; Roxburgh \& Romanuk 2006:24).

\section{Missional planning and management}

Jesus' statement, 'For which of you, intending to build a tower, does not sit down first and count the cost, whether he has enough to finish it?' (Lk 14:28), has a strong conation for importance of planning in our personal lives. This idea could also be implemented in missional planning management of the church. Dayton and Fraser (1990) submit that:

\footnotetext{
if we were Christian farmers, we would not ignore the laws of nature and simply hope for a good harvest. We would not think the more ignorant and backwards we are the more room God has to bring in harvest. (p. 27)
}

In the words of Mensah, the purpose of management in Christian organisations is to create a fertile climate for spiritual service - a sense of shared mission, wise stewardship of resources and mutual supportiveness (2005:1). He held 2. To human beings belong the plans of the heart .... Commit to the Lord whatever you do, and he will establish your plans'. 
that the purpose of a Christian ministry is not excellent management per se, for management is merely a means to the end of serving God. Thus, the vision of reaching out to humanity can only be realised with careful management. Dayton and Fraser (1990) in this light remarked that:

\begin{abstract}
Management for Christian mission aims at bringing about conditions on earth where God's kingdom comes, where people obey God's commands as they are obeyed in heaven. It aims at a success that happens only within the limits and the power of God's Spirit, in conformity with the truth and claims of the gospel, and through the agency of people gifted by the Spirit whose lives exhibit the beauty of holiness. (p. 27)
\end{abstract}

In view of this, it can be said that effective management and planning is therefore needed in the area of missions. As already explained, planning and management is primarily concerned with the most effective ways of reaching organisational goals. Therefore, it is imperative for various churches to set goals and then plan to effectively manage both the human and capital resources available to them as they participate in the missio Dei.

The unpredictable economic climate has created budgeting challenges for many organisations, and the church is no exception. This has created the need for churches to figure out the best way to manage their limited resources. Church leaders are often challenged with ensuring there is continued funding to support current programmes and fixed operational costs. This can be difficult because the financial needs of a church can be significant, and juggling limited resources can be stressful.

To this end, Callahan concludes that 'when congregations utilise effective church finance practices, they invest less time, find more creativity, and have stronger results' (Callahan 1992:3). In doing this, leadership and congregation members being assigned the responsibility of managing the capital resources of the church should have in mind that they are stewards of God's property.

The cornerstone of stewardship is the full acknowledgement and consistent practice of allowing God to direct what he wants done with what he has entrusted us to manage. Stewardship defines our practical obedience in the administration of everything under our control and everything entrusted to us. This sense of stewardship is what makes the church being first of all accountable to God. Stewardship encompasses the way we live our lives and manage our time and the resources of God. It creates the awareness that everyone shall give account of himself or herself to God and be rewarded.

\section{Management of human resources for mission}

Human beings are the most important assets of any organisation and the church is not an exception. According to Snell and Bohlander, the term 'human resources' implies that people have the capabilities that drive organisational performance (Snell \& Bohlander 2007:4). Human resource involves the commitment, skills, knowledge, potential and availability of people. It extends to all their assets whether personal and financial. A church's human resource base falls into two categories: Volunteer workers and paid church staff. How effective a denomination is in the fulfilment of the missio Dei can therefore be determined by how people and resources are managed.

The solution to faith communities' questions about how to participate in God's missional praxis is a critical, constructive dialogue or correlation between their interpretations of the realities of the global and local context and the faith resources at their disposal (Hendriks 2004:30). The Harvestime International Institute holds that as believers, each of us is a manager of spiritual resources with which God has entrusted us (Harvestime International Institute 2001:7). Willis remarked that not only does the church involve the laity, it is the laity (Willis 1988:49). It can therefore be established that every believer is called to perform a ministry. The mandate of the church in mission is not the mandate of a special class of people but every member of the body of Christ. Therefore, this makes each congregation member a missional resource for the advancement of the kingdom of God.

The missional ecclesiological orientation of LCI is not a building or an institution but a community of witness, called into being and equipped by God and sent into the world to testify to and participate in Christ's work. The church focuses on the formation of a Christian community around God's mission in and for the world within the congregation's own context and as they are being led by the Holy Spirit. Local congregations are therefore impelled to step out of their comfort zones and cross boundaries for the sake of the mission of God (World Council of Churches 2013:67).

Ephesians 4:1-16 says that Christ endowed the church with certain persons whose duty it is to equip the saints. The Greek word for equip or perfect in verse 12 means to mend. It also means to educate, to train, to guide or to enable a person fully to do a task. The equipper's task is to perfect the saints so that they can do the work of the ministry and build up the body of Christ. The primary purpose of the equippers is to enable the saints to minister and live worthy lives of humility, meekness, long suffering, forbearance and unity (Eph 1:18; 4:1-6).

In this sense, it can be said that the equippers are the human resource managers in the economy of the church. However, the equippers' or leaders' role as managers is even more needed after people are ready for the service of ministry. Human resources managers plan, direct and coordinate the administrative functions of an organisation.

Ministry team members are valued not only for their performance contributions to the ministry but also because they are members of God's family. Effective Christian 
management results in the ministry team being a family of people who care about and for one another. Management of Christian organisations is people-centred and participative.

Ministry management places a high value on cooperation and teamwork. Team members are motivated by a shared sense of vision and mission, which is more important to them than personal gain. Goals are pursued selflessly and sacrificially. How Christians work with one another is just as important as what they are striving to accomplish. A key aim of ministry management is to help team members become more Christ like. Management in Christian organisations is ultimately a partnership with God, built on prayer, faith and obedience in the participation in the missio Dei.

\section{The role of missional leadership in the management in Lighthouse Chapel International}

Management is like health; it is often easier to describe it by its absence than by its presence. The complexity of the management task rises exponentially with the size of an organisation. Although many people hold the view that there are natural or born leaders, good management is however a learned skill. People are not born with it (Dayton \& Fraser 1990:45).

Most churches and mission organisations begin with a natural leader, often one who has a strong charismatic personality, thus ability to inspire others with his or her vision of what God wants to accomplish. This type of leadership is effective so long as the leader has the time and energy to oversee the entire operation of the organisation. As soon as the organisation multiplies, it becomes very difficult for the natural leader to give day-to-day guidance; management skills are therefore needed. Dag Heward-Mills remarked that 'while the membership of most churches has increased over the past few years; the pastor's ability for handling larger crowds has not been developed' (HewardMills 2007a:187). This observation from Bishop Dag is very true, especially among Ghanaian Pentecostal churches. Many of their leaders lack the skills to properly manage their churches.

According to Hirsch (2006:152), if we really want missional church, then we must have a missional leadership system to drive it. This requires the reinterpreting of the denomination's foundational values in the light of the demands of its mission. In this regard, the missional leader needs to be a visionary, who can outlast significant opposition from within the denominational structures and can build alliances with those who desire change. In addition, the leader has to encourage signs of life within the existing structures and raise up a new generation of leaders and churches from the old (Addison 1995:90). Guder (1998:183) posits that the key to the formation of missional communities is their leadership. Leadership is a critical gift, provided by the Spirit because, as the Scripture demonstrates, fundamental change in any body of people requires leaders capable of transforming its life and being transformed themselves.

The fact that LCI has arisen beyond the oversight of its founder and is still functioning effectively points to good missional leadership. The church currently has over 1800 branches in 79 countries. The leadership and the management system of the church epitomise a balance between spiritual and organisational leadership in LCI. It is in this light that Bishop Heward-Mills advised that a good study of administration and management will do the church of God a lot of good (Heward-Mills 2007a:187).

In emphasising the responsibility of the church in planning strategies, Malphurs submits that without mission strategies, churches are only wasting their time. Hence, the strategy of the church is the vehicle that enables the church to accomplish the great commission (Malphurs 1996:30). Planning is a concept that is highly prioritised in LCI. Carefully written down plans are well communicated in the church. This strategic plan of LCI is usually developed by the Bishop Council (the highest decision-making and planning body) as they are led by the Holy Spirit, then it moves down to the general council, regional council, lay preacher's council and the stallion's council who develop strategic plans for the ministry.

The church has been organised in such a way that every activity of their church leaders is been recorded and monitored through a Web system called Pastoshep. Pastoshep is a computer programme used to keep accurate data and statistics of pastoral activities. It has afforded the church the opportunity to care and monitor all ministers in LCI. HewardMills remarked that despite the limitations as a result of limited addresses and telephone numbers in Ghana, the Pastoshep has become a reliable and technological method of assessing the work of all pastors and shepherds alike. Thus, without being there to physically see what people are doing, this computer programme keeps accurate data of what everybody in LCI is doing (Heward-Mills 2007b:184).

The Pastoshep has also helped the church in the management of their congregational membership at every location they have established a church or cell group. The programme has been designed in such a way that every detail of their members is stored on the system. The only disadvantage of the Pastoshep is that it requires Internet access everywhere it is being used. Therefore, ministers or pastors, who have churches or cell groups at locations without Internet, are required to travel to where they could have access to Internet.

In their mission approach, whenever they are to plant a church or have an open air crusade dubbed, 'Healing Jesus Evangelism Campaign', they usually send the Advance Team to the venue. The Advance Team is a special group of highly skilled and experienced individuals charged with the mandate to explore new territories and organise campaigns many weeks in advance. They make all the necessary preparations for the campaign to begin. This is done in 
conjunction with the Mission Team, the Protocol Team, the Praises and Worship Team, Medical Mission Team and the Media Team.

\section{Managing the resources of the church with a missiological focus}

The church is endowed with several resources that should be properly managed for missional purposes. Resource management is essential to any organisational success. Because every single soul in the church has a role to play, it is important to pay attention to all persons in the church as well as their gifts and talents. A balanced church is the one that has people from all walks of life active in it. There should be the young and old, educated and uneducated, rich and poor, and men and women. It is therefore imperative for churches to incorporate all sorts of people to share the burden of mission. Heward-Mills holds that more often than not, the category of people who are written off, as far as ministry is concerned, stand a chance of contributing greatly to the kingdom (Heward-Mills 2007b:3). The fact that the ministry cannot be borne by one person necessitated the training and management of the people for effective accomplishment of the church's goals. According to Gibbs and Coffey (2001:121), the focus of missional leadership is not in the first place on strategic planning or management, but on cultivating within the missional community the capacities needed for spiritual discernment and formation.

In LCI, all people from all walks of life are incorporated into the running of the church. The purpose of this approach is to equip them for the fulfilment of the mission of God. Bishop Heward-Mills remarked that he has many medical doctors, specialists, lecturers, architects and engineers, all who are serving as lay pastors (Heward-Mills 2007b:3). Thus, every individual in the church shares the burden of ministry and carrying out the mission of God. In Van Gelder's view, when we talk of a congregation, it is the discovering together of the missional vocation of the community. It is beginning to redefine 'success' and 'vitality' in terms of faithfulness to God's calling and sending. It is seeking to discern God's specific missional vocation for the entire community and for all of its members (Van Gelder 2007:33). With this worldview, the missional church understands itself to be missionary by nature - called, equipped and sent into the world by the Holy Spirit to participate fully in God's mission (Van Gelder 2005:23). The missio Dei presupposes mission communities that are witness to the work of God being carried out. The witness to God's work is through the people God calls and sets apart for this mission (Guder 2000:146).

In order to develop and equip members of the LCI to participate in the missio Dei, the Anagkazo Bible Training School was established. The Anagkazo Bible Training School was founded in 1996 by Bishop Dag Heward-Mills. The establishment of the school was prompted by Bishop Dag's desire to see young men and women trained and equipped for the work of the ministry. Anagkazo started as a 1-year part-time bible school. The first graduation took place in
November 1997 with 12 students. It later evolved into a 2-year full-time programme and in the 2006 academic year, the period of training was extended to 4 years.

Currently, Anagkazo has over 10000 students worldwide who are acquiring ministerial formation education both residentially and through online or distance learning. Many of its international students come from Africa, Europe, Asia, Australia and the Caribbean. Graduates of Anagkazo are known for their soul-winning and church-planting passion and have a strong desire to see the gospel preached to every soul everywhere (Anagkazo Bible Seminary 2013).

Pastors and ministers who graduate from the Anagkazo are sent to start churches in communities all over the world. According to the LCI church-planting approach, a group of three or more is always enough to start a church. This caused the church to send missionaries to various places and countries to plant churches. Remarkably, many of these young men and women are professionals and are therefore sent as tent-making missionaries. This approach has also helped the church to save a lot of money because these lay ministers are not being paid by the church.

\section{Lighthouse and tent-making ministry}

We live in an important time with new challenges for the advancement of the gospel. One major challenge has to do with finances. It is however an acknowledged fact that every church has a limit to its resources (Heward-Mills 2007b:10). In Cook's observation, if the members of the church who go out as missionaries are more than the church can support, the problem becomes a serious one (Cook 1971:253). This is one of the reasons why the 21st century churches should place more emphasis on 'tent-making ministry' as a strategy to overcome financial barriers in the fulfilment of the missio Dei.

Tent-making ministry refers to the activities of a matured Christian who, while dedicating himself or herself to the ministry of the gospel, receives little or no pay for church work, but performs other jobs to provide support. Specifically, tent making can also be referred to as a method of international Christian evangelism in which missionaries support themselves by working full-time in the marketplace with their skills and education, instead of receiving financial support from a church (Siemens 1999:733-741). The Apostle Paul's missionary account says that he supported himself by making tents while living and preaching in Corinth. On another occasion, he reported that he frequently performed outside work, in order not to be a financial burden to the young churches he founded (White 2014:226). Tent making is a time-proven and biblical tool, adopted by the Apostle Paul, the first missionary to integrate secular work and ministry (McNamara 2012:1).

In LCI, tent-making ministers are called lay ministers (Heward-Mills 2008:4). Bishop Heward-Mills defines a lay person or minister as someone who maintains his or her 
secular job and yet is active in the ministry of the Lord Jesus and a full-time minister as someone who has abandoned his or her secular job to concentrate fully on the ministry (Heward-Mills 2007b:7). To him, one of the greatest keys to extensive ministry work is the tent ministry (Heward-Mills 2008:1). Churches in this world that have experienced phenomenal growth have all employed the principle of using lay people for the ministry. In emphasising the degree to which the church has adapted this strategy, he wrote that:

Though I oversee a hundred churches and several thousand people at the Lighthouse Cathedral, we currently have only seven full-time pastors on staff worldwide. We have over two hundred pastors and trainee pastors within the ministry. Ninetyfive percent of them are unpaid lay people.... It is not possible to pay salaries and rent an unlimited number of houses for the staff of the ministry. Full-time staff are limited in the number and the amount of work that can be done. The use of lay people is the secret to unlimited expansion of the church. (Heward-Mills 2007b:1)

Tent making is very important as it sometimes provides Christians the chance to serve in countries normally closed to mission work. Governments hostile to Christianity often accept well-qualified teachers, computer technicians, doctors and engineers into their countries to work, even if these men and women are Christians. These professionals are able to serve the country and support themselves while exploiting that opportunity to perform mission work in those countries.

\section{Missional copycat}

Having discussed how the LCI has been able to apply the principles of missional planning and management in their participation of the missio Dei, assessment of their missional leadership formation is more or less like a kind of copycat. The term 'copycat' is usually referred to a person or thing that copies, imitates or follows the lead of another. The Cambridge Dictionary (2017) defines it as 'someone who has few ideas of their own and does or says exactly the same as someone else'.

In LCI leadership and missional formation, members and aspiring leaders are made to read books and listen to and watch the sermon of Bishop Heward-Mills. They are therefore assessed based on these books and sermons. They are required to preach prescribed sermons in their local churches, which should be in line with that of Bishop Heward-Mills.

This approach in their leadership formation leaves little or no room for aspiring leaders (church pastors) to be themselves and develop their personal capacities in sermon preparation. In their understanding, this approach is to give the church a missional brand for uniformity and also avoid any form of heresy.

The New Testament suggests that Spirit-empowered movements articulate the gospel for a particular context. If this is the case, then it means that what LCI needs is less imitation and more discernment through the Holy
Spirit. My purpose for this critical reflection of the LCI missional formation is to point out that in spite of fact that the church wants to maintain their missional brand, it is equally important not impose on minister of the church the sermons of Bishop Heward-Mills.

\section{Conclusion}

Planning and management is part of our everyday life and so it is in the life of the church. This article discusses the role of planning and management from a missional perspective by using the LCI as a case study. The article started with an overview of the nature of the 21st century church and mission. It argues that the mission theology and practice today and in the future are being shaped primarily by the dynamics of global and ecumenical impulse. The article further noted that in order for the church to be missionally relevant in the changing dynamics of the world, missional leaders and their congregation must see discernment as the first step in their involvement in the missio Dei.

The article unearthed how the LCI has used planning and management as one of the missional tools in their participation in the missio Dei. Although leadership has a major role to play in missional planning and management of the church, it is however a holistic and all-inclusive agenda. Missional planning and management should include the involvement of the Holy Spirit, congregational leadership, the entire congregation and the various resources the church is being endowed with by God.

The paper finally noted that despite the fact that LCI has been successful in applying planning and management in their participation in the missio Dei, their missional leadership formation which is in the form of a missional copycat should be looked at to make room for deeper missional discernment.

\section{Acknowledgements Competing interests}

The authors declare that they have no financial or personal relationships which may have inappropriately influenced them in writing this article.

\section{Authors' contributions}

P.W. was responsible for the conceptual and theoretical aspects of the research and finalisation of the article. B.O.A. did the field work and data collection as well as prepared the first draft of the article.

\section{Reference}

Aboderin, I., 2011, Intergenerational support and old age in Africa, Transaction Publishers, Piscataway, NJ.

Addison, S., 1995, 'A basis for the continuing Ministry of the Apostle in the Church's Mission', Doctor of Ministry, dissertation, Fuller Theological Seminary, Pasadena.

Anagkazo Bible Seminary, 2013, History of the Anagkazo bible seminary, viewed 12 September 2016, from http://anagkazobibleseminary.org/absi/home/history-ofthe-school

Balia, D. \& Kim, K. (eds.), 2010, 'Witnessing to Christ today', in Edinburgh 2010, vol. II, Regnum Books International, Oxford, UK. 
Callahan, K.L., 1992, Effective church finance, Harper Collins Publishers, San Francisco, CA.

Cambridge Dictionary, 2017, 'Copycat', viewed 01 May 2017, from http://dictionary. cambridge.org/dictionary/english/copycat

Cook, H., 1971, An introduction to Christian missions, Moody Press, Chicago, IL.

Dayton, E. \& Fraser, D., 1990, Planning strategies for world evangelization, Eerdmans Publishing Company, San Francisco, CA.

Gibbs, E. \& Coffey, I., 2001, Church next: Quantum changes in Christian Ministry, InterVarsity Press, Leicester.

Greenway, R.S. \& Kyle, J.E., 1990, Missions now: This generation, Baker Book House, Grand Rapids, MI.

Guder, D.L. (ed.), 1998, Missional Church: A vision for the sending of the Church in North America, Eerdmans, Grand Rapids, MI.

Guder, D.L., 2000, The continuing conversion of the church, Eerdmans, Grand Rapids, MI.

Harvestime International Institute, 2001, Biblical management principles, Harvestime International Institute, Colorado Springs, CO.

Hendriks, H.J., 2004, Studying congregations in Africa, Lux Verbi.BM (Pty) Ltd, Wellington.

Heward-Mills, D., 2007a, Mega Church: The anointing and the strategies, Parchment House, Accra.

Heward-Mills, D., 2007b, Lay people and the ministry, Parchment House, Accra.

Heward-Mills, D., 2008, The Tent Ministry, Lux Verbi.BM (Pty) Ltd, Wellington.

Hirsch, A., 2006, The forgotten ways: Reactivating the Missional Church, Brazos Press, Grand Rapids, MI.

Kemper, T., 2016, The missionary movement, viewed 20 March 2016, from https:// www.umcmission.org/find-resources/new-world-outlook-magazine/2016/ January/February/0107missionarymovement

Kim, K., 2009, Joining in with the spirit: Connecting world Church and local mission, Epworth, London.

Ma, W. \& Ross, C., 2010, 'Theme nine: Mission spirituality and authentic discipleship', in D. Balia \& K. Kim (eds.), Edinburg 2010: Witnessing to Christ today, pp. 223, 241, Regnum Books International, Oxford, UK.

Malphurs, A., 1996, Strategy 2000: Churches making disciples for the next millennium Kregel Resources, Grand Rapids, MI.

McNamara, D., 2012, 'Consider tent-making in spite of its challenges', Paper presented at Students Global Impact National Conference 2012, held on 17 January 2012 at Inter-City Baptist Church, Detroit.

Means, J.E., 2008, 'The purpose of management', in J.D. Berkley (ed.), Leadership handbook of management and administration, p. 350, Bakers Books, Grand Rapids, MI.
Mensah, V.P.K., 2005, Church/Ministry leadership and management, University of Cape Coast, Cape Coast.

Nadella, R., 2013, 'Redefining connectedness', Theological investigations in the church and culture, Columbia Theological Seminary, Decatur, GA.

Quampah, D., 2014, Good pastors, bad pastors: Pentecostal ministerial ethics in Ghana, Wipf and Stock Publishers, Eugene, OR.

Robbins, S. \& Coulter, M., 2002, Management, Pearson Education Press, Hudson, NJ.

Roxburgh, A.J., 2011, Missional: Joining God in the neighbourhood, Baker Books, Grand Rapids, MI.

Roxburgh, A.J. \& Romanuk, F., 2006, The missional leader: Equipping your church to reach a changing world, Jossey-Bass, San Francisco, CA.

Rush, M., 2003, Management: A biblical approach, SP Publications, Monrovia, CA.

Sanneh, L. \& Carpenter, J., 2005, The changing face of Christianity: Africa, the west, and the world, Oxford University Press, Oxford. https://doi.org/10.1093/0195177282.001.0001

Shapiro, J., 2003, Toolkit on overview of planning; CIVICUS: World alliance for citizen participation, viewed 11 September 2016, from http://www.civicus.org/view/ media/Overview $\% 20$ of $\% 20$ Planning.pdf

Shorter, A., 1978, African Christian spirituality, Geoffrey Chapman, London.

Siemens, R.E., 1999, 'Tentmakers needed for world evangelization', in R.D. Winter \& S.C. Hawthorne (eds.), Perspectives on the world Christianity movement, 3rd edn., pp. 733-741, William Carey Library, Pasadena, CA.

Snell, S. \& Bohlander, G., 2007, Human resource management, Lachina Publishing Inc., Mason.

Stewart, M.H. \& Nadia, K., 2009, Fundamentalisms and the media, Continuum International Publishing Group, New York.

Sweet, L., 2009, So beautiful: Divine design for life and the church, David C. Cook, Colorado Springs, $\mathrm{CO}$.

Van Gelder, C., 2005, 'Rethinking denominations and denominationalism in light of a missional ecclesiology', Word and World 25(1), 23-33.

Van Gelder, C., 2007, The Ministry of the missional church. A community led by the spirit, Baker Books, Grand Rapids, MI.

Wagner, P., 1987, Strategies for church growth, Gospel Light Publications, Ventura, CA.

White, P., 2014, 'A missiological study of the role of the baptism and infilling of the Holy Spirit in Ghanaian Pentecostal Churches', PhD thesis, Faculty of Theology, University of Pretoria, Pretoria.

White, P., 2016, 'Pentecostal mission spirituality: A study of the classical Pentecostal churches in Ghana', Missionalia 44(3), 251-262.

Willis, A.T., 1988, The Biblical basis of missions, Convention Press, Mishawaka, IN.

World Council of Churches, 2013, 'Together towards life', in M. Lorke \& D. Werner (eds.), Ecumenical vision for 21st century, pp. 52, 56-57, WCC Publications, Geneva. 